\title{
Isolation and molecular characterization of Salmonella spp. from chevon and chicken meat collected from different districts of Chhattisgarh, India
}

\author{
V. K. Naik ${ }^{1}$, S. Shakya ${ }^{1}$, A. Patyal ${ }^{1}$, N. E. Gade ${ }^{2}$ and Bhoomika
}

1. Department of Veterinary Public Health and Epidemiology, College of Veterinary Science and Animal Husbandry, Chhattisgarh Kamdhenu Vishwa Vidyalaya, Anjora, Durg, Chhattisgarh, India; 2. Department of Veterinary Physiology and Biochemistry, College of Veterinary Science and Animal Husbandry, Chhattisgarh Kamdhenu Vishwa Vidyalaya, Anjora, Durg, Chhattisgarh, India.

Corresponding author: A. Patyal, e-mail: anilvet01@gmail.com, VKN: vetvivek8583@gmail.com, SS: shakyadurg@gmail.com, NEG: nitingadeivri@gmail.com, B: sirsant.mannat.09@gmail.com Received: 22-01-2015, Revised: 24-04-2015, Accepted: 30-04-2015, Published online: 06-06-2015

doi: 10.14202/vetworld.2015.702-706 How to cite this article: Naik VK, Shakya S, Patyal A, Gade NE, Bhoomika (2015) Isolation and molecular characterization of Salmonella spp. from chevon and chicken meat collected from different districts of Chhattisgarh, India, Veterinary World 8(6): 702-706.

\begin{abstract}
Aim: The aim was to assess the prevalence of Salmonella in raw chevon and chicken meat sold in the retail meat shops situated in and around Durg, Rajnandgaon, Dhamtari, Raipur, and Bilaspur districts of Chhattisgarh. Studies were also conducted to find out the antibiotic resistance in Salmonella isolates.
\end{abstract}

Materials and Methods: A total of 400 samples comprising of 200 chevon meat and 200 chicken meat samples were processed for isolation of Salmonella and all isolates were further confirmed on the basis of cultural and biochemical characters and by targeting invA gene of Salmonella. All Salmonella isolates were also examined for their antimicrobial drug susceptibility/resistance pattern against commonly used antibiotics.

Results: Out of 400 samples, the prevalence of Salmonella in chevon and chicken meat was found 9\% and 7\% respectively, with an overall prevalence of $8 \%$. Polymerase chain reaction targeting invA gene of Salmonella showed positive result with 31 isolates. All 32 Salmonella isolates were found to be highly sensitive to ciprofloxacin while $96.87 \%, 96.87 \%$ and 93.75\% were sensitive to gentamicin, imipenem, and ceftazidime, respectively. $93.75 \%$ and $59.37 \%$ isolates were resistant to erythromycin and oxytetracycline, respectively. Out of 32, 14 isolates had multiple antibiotic resistance index equal to or more than 0.2 .

Conclusion: Salmonella in chevon and chicken meat samples is prevailing in the areas of sampling due to poor hygienic conditions and also demonstrated the varied spectrum of antimicrobial resistance, including several multiple drug resistance phenotypes. Therefore, the present study emphasizes the need for continued surveillance of zoonotic foodborne pathogens including antimicrobial-resistant variants throughout the food production chain.

Keywords: chevon, Chhattisgarh, chicken, isolation, molecular characterization, Salmonella.

\section{Introduction}

Among all foodborne diseases, Salmonella is identified as a leading cause of foodborne illness in humans and animals resulting in 16 million annual cases of typhoid fever, 1.3 billion cases of gastroenteritis and 3 million deaths worldwide [1]. In India, salmonellosis is endemic and its importance as potential zoonosis needs no emphasis as it causes heavy economic losses every year [2]. Outbreaks due to Salmonella have been associated with a wide variety of foods especially those of animal origin [3] such as meat, chicken, egg, and sometimes vegetables in the food chain $[4,5]$.

The standard conventional cultural techniques to identify Salmonella spp. are time-consuming and can require up to 7 days for confirmation. Polymerase chain reaction (PCR) based methods combine simplicity with a potential for high specificity and sensitivity in detection of Salmonella. Amplification

Copyright: The authors. This article is an open access article licensed under the terms of the Creative Commons Attributin License (http:// creative commons.org/licenses/by/2.0) which permits unrestricted use, distribution and reproduction in any medium, provided the work is properly cited. of invA gene of Salmonella has been reported as a suitable target for PCR amplification, with potential diagnostic applications [6]. During past two decades, antibiotic-resistant Salmonella has emerged and become a serious public health issue worldwide [7]. Currently, there are several evidences of therapeutic failure due to the increasing incidence of antimicrobial resistance among Salmonella species [8].

Therefore, the present study was conducted to assess the prevalence of Salmonella in chevon and chicken meat collected from five districts of Chhattisgarh, India. Studies were also conducted to find out the antibiotic resistance in Salmonella isolates.

\section{Materials and Methods}

\section{Ethical approval}

Live animals were not used in this study, so ethical approval was not necessary. Meat samples were collected from retail meat shops.

\section{Sample collection}

A total of 400 samples comprising Chevon meat $(n=200)$ and Chicken meat $(n=200)$ were collected from retail meat shops situated in and around Durg, Rajnandgaon, Dhamtari, Raipur and Bilaspur districts 
of Chhattisgarh randomly during September 2013 to August 2014. All meat samples were aseptically collected in sterile polythene bags and transported in refrigerated conditions to the laboratory as soon as possible and processed within $5 \mathrm{~h}$ for bacteriological examination.

\section{Isolation and biochemical characterization}

Isolation of Salmonella spp. from chevon and chicken meat samples was carried out as per the ISO 6579:2002 protocol [9] with slight modifications. Briefly, for pre-enrichment $25 \mathrm{~g}$ of meat sample was blended and discharged in $225 \mathrm{ml}$ of sterilized buffered peptone water (BPW) (HiMedia, India) and incubated at $37^{\circ} \mathrm{C}$ for $20-24 \mathrm{~h}$. One $\mathrm{ml}$ of culture from BPW broth was inoculated into the tube containing $10 \mathrm{ml}$ sterile tetrathionate broth (TT) (HiMedia, India) for selective enrichment and further incubated at $37^{\circ} \mathrm{C}$ for $24 \mathrm{~h}$. A loop full culture was then picked from TT broth and streaked onto the multiple selective plating media i.e. brilliant green agar (BGA) and bismuth sulfite agar (BSA) (HiMedia, India). All the inoculated plates were incubated at $37^{\circ} \mathrm{C}$ for $24 \mathrm{~h}$. Moderately large, moist, smooth, and colorless colonies with pink background on BGA and typical black colony surrounded by brownish-black zone with metallic sheen on BSA were considered as Salmonella. The characteristic colonies of Salmonella spp. from selective plating media were further streaked on differential plating media, MacConkey's lactose agar (HiMedia, India), and incubated at $37^{\circ} \mathrm{C}$ for $24 \mathrm{~h}$. Characteristic colorless colonies of Salmonella were transferred to nutrient agar slant for further identification and biochemical characterization. All Salmonella isolates were biochemically tested using indole (I), methyl red (M), voges proskauer (Vi), citrate (C), triple sugar iron (TSI), and urease tests as per the protocol described by Ewing [10]. The colonies showing Salmonella specific IMViC pattern (-+-+) were further inoculated on TSI slants and colonies producing alkaline slant (pink) and acidic butt (yellow) with or without $\mathrm{H}_{2} \mathrm{~S}$ production (blackening) were tested for urease production on urea agar slants. All the urease negative isolates were considered as biochemically confirmed Salmonella isolates.

\section{Molecular characterization}

All biochemically confirmed Salmonella isolates were further confirmed by targeting invA gene. For PCR, template DNA was isolated by boiling and snap chill method as outlined by Nagappa et al. [11]. Purity and concentration of DNA were detected by $0.8 \%$ agarose gel electrophoresis. Recommended primer set of forward primer (26 bp): 5'- GTGAAATTATCGC CACGTTCGGGCAA-3' and reverse primer (22 bp): 5'- TCATCGCACCGTCAAAGGAACC-3' were used to obtain a predicted product size of $284 \mathrm{bp}$ [12]. Primers of invA gene used in this study were synthesized from Imperial Life Sciences (P) Limited, Gurgaon, Haryana, India. PCR was standardized following the protocol of Rahn et al. [12] with some modifications using the thermocycler (Mastercycler, Eppendorf, Germany). Briefly, in a reaction mixture, $2.5 \mu \mathrm{l}$ of $\times 10$ taq buffer, $1.5 \mathrm{mM} \mathrm{MgCl}, 50 \mu \mathrm{M}$ of each deoxyribonucleotide triphosphate, $10 \mathrm{pmol}$ of each primers, $1 \mathrm{U}$ Taq polymerase, $3 \mu \mathrm{l}$ of template DNA, and nuclease free water to make the total volume $25 \mu \mathrm{l}$ were used. PCR-cycling was performed with initial denaturation of $94^{\circ} \mathrm{C}$ for $5 \mathrm{~min}$, followed by 30 cycles of denaturation at $94^{\circ} \mathrm{C}$ for $1 \mathrm{~min}$, annealing at $55^{\circ} \mathrm{C}$ for $1 \mathrm{~min}$, and extension at $72^{\circ} \mathrm{C}$ for $1 \mathrm{~min}$. Final extension was done at $72^{\circ} \mathrm{C}$ for $5 \mathrm{~min}$. After the completion of reaction cycles, the PCR product was electrophoresed on $1.5 \%$ agarose gel stained with ethidium bromide $(0.5 \mu \mathrm{g} / \mathrm{ml})$, analyzed under ultraviolet transilluminator (Biometra) and photographed under Gel Documentation System (Gel Doc ${ }^{\mathrm{TM}}$ XR, Biorad, USA). All the biologicals used during the present study were procured from Thermo Scientific (USA), Genetix (India), and Bangalore Genei (India).

\section{Antibiotic sensitivity testing}

All Salmonella isolates were examined for their antimicrobial drug susceptibility/resistance pattern by disc diffusion technique [13]. Antibiotic discs impregnated with oxytetracycline $(\mathrm{O}, 30 \mu \mathrm{g})$, amoxycillin $(\mathrm{AX}, 10 \mu \mathrm{g})$, cephalexin $(\mathrm{CN}, 30 \mu \mathrm{g})$, ciprofloxacin (CIP, $5 \mu \mathrm{g}$ ), gentamicin (GEN, $30 \mu \mathrm{g}$ ), erythromycin $(\mathrm{E}, 10 \mu \mathrm{g})$, cefotaxime (CTX, $10 \mu \mathrm{g})$, nalidixic acid (NA, $30 \mu \mathrm{g}$ ), ampicillin (AMP, $10 \mu \mathrm{g}$ ), ceftazidime (CAZ, $30 \mu \mathrm{g}$ ), imipenem (IPM, $10 \mu \mathrm{g}$ ), amoxyclav (AMC, $30 \mu \mathrm{g}$ ), cefixime (CFM, $5 \mu \mathrm{g}$ ), and meropenem (MRP, $10 \mu \mathrm{g}$ ) (HiMedia, India) were used. The diameter of the zones of complete inhibition was measured and compared with the zone size interpretation chart provided by the supplier and were graded as sensitive, intermediate, and resistant. The multiple antibiotic resistance (MAR) index was also calculated for all Salmonella isolates following the protocol described by Krumperman [14], by applying formula a/b where "a" is the number of antibiotics to which an isolate was resistant and " $b$ " is the number of antibiotics to which the isolates were exposed.

\section{Results and Discussion}

Based on the cultural characteristics and biochemical characterization, a total of 32 presumptive Salmonella isolates were isolated (Table-1), with an overall prevalence of $8 \%$. In chevon meat samples, highest prevalence of Salmonella was recorded in Durg district (12.5\%), followed by Raipur and Dhamtari $(10 \%)$, Rajnandgaon $(7.5 \%)$, and Bilaspur (5\%) districts. In chicken meat samples, highest prevalence of Salmonella was seen in Rajnandgaon (12.5\%) district followed by Raipur and Bilaspur (7.5\%), Durg (5\%), and Dhamtari (2.5\%) districts.

The overall prevalence of Salmonella in chevon meat was found $9 \%$ which corroborates with the previous reports $[15,16]$. However, higher prevalence 
Table-1: Prevalence of Salmonella in chevon and chicken meat samples collected from different districts of Chhattisgarh.

\begin{tabular}{|c|c|c|c|c|c|c|}
\hline \multirow[t]{2}{*}{ District } & \multicolumn{3}{|c|}{ Chevon meat } & \multicolumn{3}{|c|}{ Chicken meat } \\
\hline & $\begin{array}{c}\text { Number of } \\
\text { samples } \\
\text { processed }\end{array}$ & $\begin{array}{l}\text { Number } \\
\text { of isolates } \\
\text { recovered }\end{array}$ & $\begin{array}{c}\text { Prevalence } \\
(\%)\end{array}$ & $\begin{array}{c}\text { Number of } \\
\text { samples } \\
\text { processed }\end{array}$ & $\begin{array}{l}\text { Number } \\
\text { of isolates } \\
\text { recovered }\end{array}$ & $\begin{array}{c}\text { Prevalence } \\
(\%)\end{array}$ \\
\hline Durg & 40 & 5 & 12.5 & 40 & 2 & 5 \\
\hline Rajnandgaon & 40 & 3 & 7.5 & 40 & 5 & 12.5 \\
\hline Raipur & 40 & 4 & 10 & 40 & 3 & 7.5 \\
\hline Dhamtari & 40 & 4 & 10 & 40 & 1 & 2.5 \\
\hline Bilaspur & 40 & 2 & 5 & 40 & 3 & 7.5 \\
\hline Total & 200 & 18 & 9 & 200 & 14 & 7 \\
\hline
\end{tabular}

rates of $13.88 \%$ [17], $14.20 \%$ [18], and $38.33 \%$ [19] were reported from different regions. On the contrary, lower prevalence rates of $1.25 \%$ [20], 2.5\% [21], and $3.3 \%$ [22] were also reported in chevon meat by several investigators. In case of chicken meat, 7\% prevalence of Salmonella was recorded; this is in accordance with earlier reports [17,23-25]. However, lower prevalence rate of $0.94 \%$ [26], $1.5 \%$ [27], and $4 \%$ [28] were reported by others. On the contrary, higher prevalence rate of $23.7 \%$ [29], 28.33\% [19], $30 \%$ [30], 31.99\% [31], and 44\% [32] were observed in chicken meat samples in earlier findings. Differences in prevalence rates of Salmonella spp. from chevon and chicken meat samples in various studies may be attributed to multiple factors, such as geographic and seasonal variation, variations in sampling procedures and sample size, animal management practices, hygienic conditions during production and processing of meat and meat products or due to differences in the sensitivity and specificity of different isolation methods used.

Molecular characterization of biochemically confirmed Salmonella isolates exhibit the desirable PCR product of $284 \mathrm{bp}$ size of invA gene (Figure-1). Presence of $i n v A$ gene confirms the invasive strains of Salmonella at the genus level. During the study, invA gene was amplified from 31 Salmonella isolates. The results of our study are in agreement to earlier findings $[29,33,34]$. It is speculated that strains without invA gene are not invasive, or that they might be using other invasive mechanisms. However, their absence in Salmonella seems to be rare [6].

All 32 Salmonella isolates were found to be highly sensitive to ciprofloxacin while $96.87 \%$, $96.87 \%$ and $93.75 \%$ were sensitive to gentamicin, imipenem, and ceftazidime, respectively. The $93.75 \%$ and $59.37 \%$ isolates were resistant to erythromycin and oxytetracycline, respectively. Varying degree of sensitivity was found against amoxyclav, cefixime $(81.25 \%$ each), nalidixic acid, amoxicillin and cephalexin $(78.12 \%$ each), ampicillin $(75 \%)$, and cefotaxime (59.37\%). Sample wise antibiogram study revealed that all the isolates from chicken meat samples were $100 \%$ resistant to erythromycin whereas $88.88 \%$ of chevon meat isolates were resistant to erythromycin. In case of oxytetracycline, the order of resistance in chevon meat samples was $(72.22 \%)$

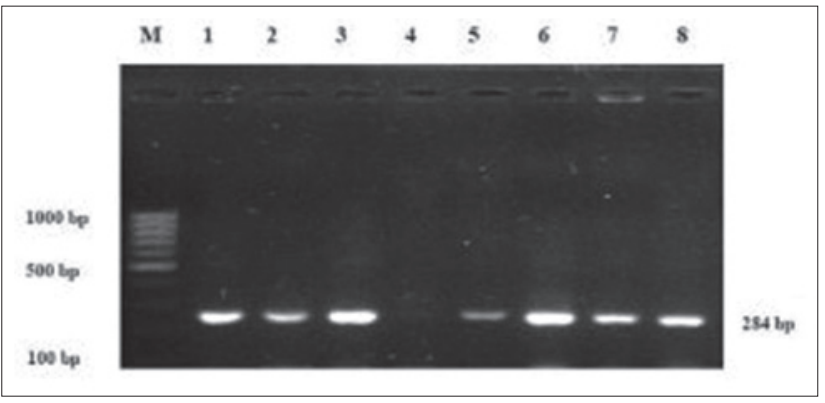

Figure-1: Agarose gel electrophoresis showing amplified polymerase chain reaction product of invA gene. Lane $M$ : 100 bp DNA Ladder, Lane 1-3 and 5-8: Salmonella isolates with invA positive amplicons (284 bp), Lane 4: Negative control (No Template DNA added).

followed by chicken meat (42.85\%). Highest MAR index was 0.50 (one isolate) followed by 0.42 (one isolate), 0.35 (one isolate), 0.28 (three isolates), 0.21 (eight isolates), 0.10 (nine isolates), and 0.07 (eight isolates). The minimum MAR index 0 was shown by one isolates. Out of 32, 14 isolates were found to have MAR index equal to or more than 0.2 , thus indicated the injudicious use of antibiotics. Similarly Jaulkar et al. [35] also reported MAR index ranging from 0.06 to 0.53 and found 10 out of 11 isolates are having MAR index more than 0.2. Hence, the present study reveals that Salmonella isolates from chevon and chicken meat are resistant to more than one antibiotic indicating the prevalence of multidrug resistant Salmonella in foods of animal origin. Findings of our study are in accordance with previous reports $[29,36]$.

\section{Conclusion}

Prevalence of Salmonella in chevon meat samples was found $9 \%$ whereas $7 \%$ in chicken meat samples in Durg, Raipur, Dhamtari, Rajnandgaon, and Bilaspur Districts of Chhattisgarh, pose a major threat for spread of Salmonellosis in humans. Salmonella needs special concern because of poor hygienic conditions prevailing in the areas of sampling which ultimately favors its spread. The isolates also exhibit the presence of invA gene thus confirms their invasiveness. The result of the study also demonstrated the varied spectrum of antimicrobial resistance, including several multiple drug resistance phenotypes among Salmonella isolates. Overall, antimicrobial resistance phenotypes were similar between Salmonella isolates recovered from 
chevon and chicken meat samples. This highlights the need for continued surveillance of zoonotic foodborne pathogens including antimicrobial-resistant variants throughout the food production chain.

\section{Authors' Contributions}

SS designed and planned this research work. VKN collected the samples and executed the isolation, biochemical, molecular characterization work. VKN and B carried out the antibiotic sensitivity assay of all isolates. AP analyzed the data and monitored the isolation, biochemical characterization and antibiotic sensitivity assay. NEG was involved in the molecular characterization experiment. All authors contributed equally in preparation and revision of the manuscript. All authors read and approved the final manuscript.

\section{Acknowledgments}

The authors are highly thankful to the Dean, College of Veterinary Science and Animal Husbandry, Chhattisgarh Kamdhenu Vishwa Vidyalaya, Anjora, Durg, Chhattisgarh, India for providing necessary financial assistance and instrumentation facilities to carry out this research work.

\section{Competing Interests} interests.

The authors declare that they have no competing

\section{References}

1. Bhunia, A.K. (2008) Salmonella enteric. In: Foodborne Microbial Pathogens: Mechanisms and Pathogenesis. Springer Science + Business Media, LLC, United States of America. p201-215.

2. Rahman, H. (2002) Some aspects of molecular epidemiology and characterisation of Salmonella typhimurium isolated from man and animals. Indian J. Med. Res., 115: 108-112.

3. Hernandez, T., Sierra, A., Rodrigue-Alvarez, C., Torres, A., Arevalo, M.P., Calvo, M. and Arias, A. (2005) Salmonella enteric serotypes isolated from imported frozen chicken meat in the Canary Islands. J. Food Prot., 68(12): 2702-2706.

4. Bouchrif, B., Paglietti, B., Murgia, M., Piana, A., Cohen, N., Ennaji, M.M., Rubino, S. and Timinouni, M. (2009) Prevalence and antibiotic-resistance of Salmonella isolated from food in Morocco. J. Infect. Dev. Ctries., 3(1): 35-40.

5. Eblen, D.R., Barlow, K.E. and Naugle, A.L. (2006) U.S. food safety and inspection service testing for Salmonella in selected raw meat and poultry products in the United States, 1998 through 2003: An establishment-level analysis. J. Food Prot., 69(11): 2600-2606.

6. Malorny, B., Bunge, C. and Helmuth, R. (2003) Discrimination of d-tartrate-fermenting and non fermenting Salmonella enterica subsp. enterica isolates by genotypic and phenotypic methods. J. Clin. Microbiol., 41(9): 4292-4297.

7. Kaye, K.S., Engemann, J.J., Fraimow, H.S. and Abrutyn, E. (2004) Pathogens resistant to antimicrobial agents: Epidemiology, molecular mechanisms, and clinical management. Infect. Dis. Clin., 18(3): 467-511.

8. Arslan, S. and Eyi, A. (2010) Occurrence and antimicrobial resistance profile of Salmonella species in retail meat products. J. Food Prot., 73: 1613-1617.

9. ISO-6579. (2002) Microbiology - General Guidance on Methods for the Detection of Salmonella. $4^{\text {th }}$ ed. International Organisation for Standardization, Geneva, Switzerland.

10. Ewing, W.H. (1986). Edwards and Ewing's Identification of Enterobacteriaceae. $4^{\text {th }}$ ed. Elsevier Science Publishing Co., Inc., New York.

11. Nagappa, K., Tamuly, S., Brajmadhuri, Saxena, M.K. and Singh, S.P. (2007) Isolation of Salmonella typhimurium from poultry eggs and meat of Tarai region of Uttaranchal. Indian J. Biotechnol., 6(3): 407-409.

12. Rahn, K., De Grandis, S.A., Clarke, R.C., McEwen, S.A., Galan, J.E., Ginocchio, C., Curtiss, R. and Gyles, C.L. (1992) Amplification of an invA gene sequence of Salmonella typhimurium by polymerase chain reaction as a specific method of detection of Salmonella. Mol. Cell. Probes, 6(4): 271-279.

13. Wayne, P.A. (2010) In: Performance Standards for Antimicrobial Susceptibility Testing: Twenty-First Informational Supplement M100-S20. Vol. 30. Clinical and Laboratory Standards Institute, Wayne, PA. p46.

14. Krumperman, P.H. (1983) Multiple antibiotic resistance indexing of Escherichia coli to identify high-risk sources of faecal contamination of foods. Appl. Environ. Microbiol., 46(1): 165-170.

15. Eze, V.C. and Ivuoma, N. (2012) Evaluation of microbial quality of fresh goat milk sold in Umuahia market, Abia state, Nigeria. Pak. J. Nutr., 11(9): 782-786.

16. Ahmad, M.U.D., Sarar, A., Najeeb, M.I., Nawaz, M., Anjum, A.A., Ali, M.A. and Mansur, N. (2013) Assessment of microbial load of raw meat at abattoirs and retail outlets. J. Anim. Plant Sci., 23(3): 745-748.

17. Panda, A.K., Kumar, A., Thakur, S.D. and Shalmali (2012) Evaluation of bacteriological quality of meat and meat products in Palam valley of North West Himalayas. J. Vet. Pub. Health, 10(1): 21-25.

18. Odey, M.O., Mboso, E.O., Ujong, U.P., Johnson, J.T., Gauje, B. and Ategwu, M.A. (2013) Microflora analysis of selected meat and meat products from Calabar, cross river state - Nigeria. Arch. Appl. Sci. Res., 5(3): 50-56.

19. Moon, A.H. (2011) Studies on: Prevalence \& antibiogram of Salmonella species of polluted meat origin. Asiat. J. Biotech. Res., 2(4): 447-453.

20. Lambey, H.S., Verma, A.K., Jain, U., Mahima and Bisht, B. (2009) Bacteriological quality of chevon and pork in Mathura city. J. Vet. Publ. Health, 7(2): 141-143.

21. Zubair, A.I. and Ibrahim, K.S. (2012) Isolation of Salmonella from slaughtered animals and sewage at Zakho abattoir, Kurdistan region, Iraq. Res. Opin. Anim. Vet. Sci., 3(1): 20-24.

22. Dabassa, A. and Bacha, K. (2012) The prevalence and antibiogram of Salmonella and Shigella isolated from abattoir, Jimma town, South west Ethiopia. Int. J. Biol. Pharm. Res., 3(4): 143-148.

23. Dahal, N. (2007) Prevalence and antimicrobial resistance of Salmonella in imported chicken Carcasses in Bhutan. Master Thesis. Chiang Mai University and Freie University, Berlin.

24. Hue, O., Bouquin, S.L., Lalande, F., Allain, V., Rouxel, S., Petetin, I., Quesne, S., Laisney, M.J., Gloaguen, P.Y., Picherot, M., Salvat, G., Bougeard, S. and Chemaly, M. (2011) Prevalence of Salmonella spp. on broiler chicken carcasses and risk factors at the slaughterhouse in France in 2008. Food Control, 22(8): 1158-1164.

25. Patyal, A., Gangil, R., Singh, P.K., Mathur, K.N. and Sudan, V. (2012) Bacteriological quality of market chicken meat in Jaipur city. J. Vet. Pub. Health, 10(1): 45-48.

26. Shekhar, C., Upadhyay, A.K. and Singh, S.P. (2013) Prevalence of Salmonella in foods of animal origin and its public health significance. J. Vet. Pub. Health, 11(1): 57-60.

27. Kumar, Y., Sharma, A., Sehgal, R. and Kumar, S. (2008) Distribution trends of Salmonella serovars in India (20012005). Trans. Roy. Soc. Trop. Med. Hyg., 103(4): 390-394. 
28. Rabie, N.S., Khalifa, N.O., Radwan, M.E.I. and Afify, J.S.A. (2012) Epidemiological and molecular studies of Salmonella isolates from chicken, chicken meat and human in Toukh, Egypt. Glob. Vet., 8(2): 128-132.

29. Kaushik, P., Anjay, Kumari, S., Bharti, S.K. and Dayal, S. (2014) Isolation and prevalence of Salmonella from chicken meat and cattle milk collected from local markets of Patna, India. Vet. World, 7(2): 62-65.

30. Akhtar, F., Hussain, I., Khan, A. and Rahman, S.U. (2010) Prevalence and antibiogram studies of Salmonella enteritidis isolated from human and poultry sources. Pak. Vet. J., 30(1): 25-28.

31. Ruban, S.W., Thiyageeswaran, M. and Sharadha, R. (2010) Isolation and identification of Salmonella spp. from retail chicken meat by polymerase chain reaction. Int. J. Microbiol. Res., 1(3): 106-109.

32. Fallah, S.H., Asgharpour, F., Naderian, Z. and Moulana, Z.
(2013) Isolation and determination of antibiotic resistance patterns in nontyphoid Salmonella spp isolated from chicken. Int. J. Entric Pathog., 1(1): 17-21.

33. Salehi, T.Z., Mahzounieh, M. and Saeedzadeh, A. (2005) Detection of InvA gene in isolated Salmonella from broilers by PCR method. Int. J. Poult. Sci., 4(8): 557-559.

34. Shanmugasamy, M., Velayutham, T. and Rajeshar, J. (2011) InvA gene specific PCR for detection of Salmonella from broilers. Vet. World, 4(12): 562-564.

35. Jaulkar, A.D., Zade, N.N., Katre, D.D., Khan, W.A., Chaudhari, S.P. and Shinde, S.V. (2011) Plasmid characterization of Salmonella isolated from foods of animal origin. J. Vet. Pub. Health, 9(1): 25-28.

36. Kumar, T., Mahajan, N.K. and Rakha, N.K. (2012) Isolation and prevalence of Salmonella serovars from poultry in different parts of Haryana, India. Indian J. Anim. Sci., 82(6): 557-560.

$* * * * * * * *$ 